Publisher: Faculty of Agronomy Čačak

\title{
Evaluation of innovative and environmentally safe growing practice suitable for sustainable management of plum orchards
}

\author{
Marijana Pešaković1* ${ }^{*}$ Ivana Glišić ${ }^{1}$, Jelena Tomić1 ${ }^{1}$ Žaklina Karaklajić-Stajić $^{1}$, Boris Rilak ${ }^{1}$, \\ Leka Mandić2 ${ }^{\text {, Dragutin Đukić } 2}$
}

${ }^{1}$ Fruit Research Institute, Čačak, Kralja Petra I 9, 32000 Čačak, Republic of Serbia

${ }^{2}$ University of Kragujevac, Faculty of Agronomy in Čačak, Cara Dušana 34, 32000 Čačak, Republic of Serbia

*Corresponding author: mpesakovic@institut-cacak.org

Received 22 May 2020; Accepted 1 July 2020

\begin{abstract}
A B S T R A C T
Intensive agricultural development based on the long-term and excessive use of chemical nitrogen fertilizers significantly contributes to a series of undesirable effects and results in environmental pollution. In line with the above, there is a pressing need for major changes in agricultural production management. Bearing in mind that fertilization strategy, among other practices, plays an important role in improving the growing technology of different fruit crops, we considered that the above mentioned problems could be overcome by introducing an environmentally safe and innovative practice inplum growing technology as well. Accordingly, a comparative study was conducted to evaluate the effects of biofertilizer (a combination of nitrogen-fixing and phosphorus-mineralizing bacteria including Azotobacter chroococcum, Bacillus megatherium and Bacillus subtilis) and chemical fertilizer (a water-soluble chemical fertilizer supplemented with the microelements $\mathrm{B}, \mathrm{Cu}, \mathrm{Fe}, \mathrm{Mn}$ and $\mathrm{Zn}$ )on'Čačanska Lepotica' and 'Stanley' plum cultivars. Morphometric characteristics (fruit weight, length and width), internal quality traits (soluble solids content and firmness) and chemical properties (total phenolic content and total antioxidant activity) of the fruit of the tested plum cultivars were assessed. The obtained results indicate that the substitution of chemical fertilization with biofertilization in 'Čačanska Lepotica' and 'Stanley' is a justified practice. Furthermore, this approach seems to havepotential as an appropriate technique in commercial plum production, which may improve yield-attributing characteristics and the phytochemical content of plum fruits.
\end{abstract}

Keywords: microbial fertilizer, chemical fertilizer, plum, productivity, quality.

\section{И 3 В 0 Д}

Интензивни развој пољопривредне производње заснован на дугорочној и прекомерној употреби минералних азотних ђубрива значајно доприноси низу нежељених ефеката и резултира загађењем животне средине. У складу са тим, неопходне су крупне и брзе промене у пољопривредној производњи. Имајући у виду да исхрана игра важну улогу у технологији гајења различитих врста воћака, сматрали смо да би се наведени проблеми могли превазићи увођењем иновативних и по животну средину безбедних производа и техника у постојећу технологију гајења различитих врста воћака, укључујући и шљиву.

Сходно томе, у засаду шљиве сорҢичанска лепотица' и 'Stanley' спроведена су упоредна проучавања утицаја биофертилизације (комбинација азото-фиксирајућих и фосфо-минерализирајућих бактерија: Azotobacter chroococcum, Bacillus megatherium и Bacillus subtilis) и употребе минералног хранива (водотопиво минерално храниво са додатком микроелемената: $\mathrm{B}, \mathrm{Cu}, \mathrm{Fe}, \mathrm{Mn}$ и $\mathrm{Zn})$. Испитивања су обухватала оцену масе, дужине, ширине и чврстине плода, као и садржаја растворљиве суве материје, укупних фенола и укупне антиоксидативне активности наведених сорти шљиве. Добијени резултати указују на чињеницу да је замена минералних хранива биофертилизаторима код сорти шљиве 'Чачанска лепотица' и 'Stanley' оправдана мера. Поред тога, може се рећи да наведена технологија представља потенцијал и за комерцијалну производњу шљиве и може допринети побољшању приноса и фитохемијском саставу плодова шљиве.

Кључне речи: микробиолошко храниво, минерално храниво, шљива, продуктивност, квалитет.

\section{Introduction}

The plum (Prunus domestica L.) is the most widespread fruit crop in the Republic of Serbia of high economic and social importance. In the cultivar structure, the leading place is occupied by cultivars developed at the Fruit Research Institute Čačak (Republic of Serbia) such as 'Čačanska Lepotica' and 'Čačanska Rodna'. In addition, an important position is held by the 'Stanley' cultivar developed in the USA.
The Republic of Serbia is the third largest producer of plums in the world, just behind China and Romania, accounting for $4.1 \%$ of global production (Vlahović and Zdravković 2016). However, in Serbia, the plum is mostly used for processing into a traditional plum alcoholic drink called 'Šljivovica' (Milošević et al. 2010), while its use for fresh consumption is quite small. Since consumers' requests for fresh plum fruits are constantly increasing due to their health-promoting effects, recent trends have encouraged the development of new growing technologies associated 
with an increased synthesis of phenolic compounds, as well as with obtaining fruits rich in phytochemicals.

Fertilization is one of basic cultural practices in orchards, which contributes most to the efficiency and intensity of production. However, improper fertilization (excessive and indiscriminate use of chemical fertilizers) causes not only economic inefficiency but also damage to the environment and, in certain situations, harms the plants themselves and human beings who consume them (Singh et al. 2012). As determined by Bockman et al. (1990), more than $50 \%$ of the applied chemical fertilizers are not adopted by plants, but are lost in different ways instead. Pešaković et al. $(2007 ; 2012)$ pointed up that a high application rate of chemical fertilizers (above $600 \mathrm{~kg}$ ha $^{-1}$ of NPK) in plum growing technology results in a decrease of the number and diversity of microorganisms in plum rhizosphere and reduces the production capacity. Therefore, we thought it was important to find a new fertilizer strategy in order to achieve and maintain an optimum balance between growth and productivity and obtain high nutritional quality of the fruit, which will further promote the existing plum growing technology, and at the same time preserve the environment.

Current trends, among other things, point to biofertilization, primarily the application of living cells of microorganisms. Living cells of microorganisms accelerate the mineralization of organic residues in soil, thereby making nutrients more available. At the same time, due to the effect of living microbial cells from biofertilizer, the uptake of heavy metals decreases (Lèvai et al. 2008). Mosa et al. $(2014 ; 2015)$ considered biofertilization in fruit growing a healthy alternative and/or supplement to chemical fertilizers. VonBennewitz and Hlusek (2006) also found biofertilization to be a beneficial technique in stimulating growth and fruiting of pomes and stone fruits. The promoting effect of yeast on growth characteristics, nutritional status as well as physical and chemical characteristics of fruits of 'Kelsey' plum trees were also observed by Mansour et al. (2011). Pešaković et al. (2016; 2017) emphasized that biofertilization is an important factor that significantly affects productivity as well as antioxidant features in cv. 'Čačanska Lepotica'.

In line with the aforementioned, the present study aimed to improve the existing plum growing technology and encourage sustainable plum production through a comparative examination of the effects of bacterial fertilizer and chemical fertilizer on quality traits of plum cvs. 'Čačanska Lepotica' and 'Stanley'.

\section{Material and methods}

\subsection{Plant material and experimental design}

The study was conducted on plum cvs. 'Čačanska Lepotica' and 'Stanley' during two consecutive seasons (2016-2017 and 2017-2018). The plum orchard was established in autumn 2003 in the village of Gornja Gorevnica near Čačak, Western Serbia $\left(20^{\circ} 57^{\prime} 48^{\prime \prime}\right.$ N; $20^{\circ} 19^{\prime} 31^{\prime \prime}$ E; $396 \mathrm{~m}$ a. s. l.). The experiment was replicated thrice in a randomized block design. Myrobalan seedling (Prunus cerasifera Ehrh.) was used as a rootstock. Planting space was $4 \times 2 \mathrm{~m}(1,250$ trees $\mathrm{ha}^{-1}$ ). The trees were trained to the spindle bush system. Standard cultural practices typical of a high intensity growing system, except irrigation, were used.

\subsection{Treatments}

Treatments included two fertilizer types i.e. biofertilizer and chemical fertilizer. For the purpose of biofertilization, a liquid fertilizer consisting of nitrogen-fixing and phosphorus-mineralizing bacteria was used (Azotobacter chroococcum, Bacillus megatherium, Bacillus subtilis). Bacterial titer in the inoculum ranged from $20-40 \times 10^{6} \mathrm{CFU} \mathrm{cm}^{-3}$. For chemical fertilization, a water-soluble fertilizer commercially named Murtonik, $\mathrm{K}+\mathrm{N}$ (EFTHYMIADIS S.A., Greece) supplemented with microelements (B, $\mathrm{Cu}$, $\mathrm{Fe}, \mathrm{Mn}, \mathrm{Zn}$ ) was used. Both types of fertilizers were applied by watering at the beginning of the growing season and by spraying during the growing period from May until mid-July every 20 days. Untreated trees served as control.

\subsection{Parameters tested}

To determine fruit morphometric traits, twenty five fruits were sampled at harvest maturity in the experimental field. Samples were taken from the southfacing side of trees 1-1.5 m above the ground. In representative fruit samples, average fruit weight was determined using an Adventurer Pro AV812M technical scale (Ohaus Corporation, Switzerland) and fruit dimensions (length, width) were taken by a digital caliper (0-150 mm, Kronen GmbH, Kehl am Rhein, Federal Republic of Germany). In the same samples, internal fruit quality traits were evaluated by determining fruit impact firmness using a hand-held shore-type penetrometer (FT 327, Effegi, Italy) and soluble solids content was measured by a binocular refractometer (Carl Zeiss, Germany). The data were expressed in $\mathrm{g}, \mathrm{mm}, \mathrm{N}$ and ${ }^{\circ} \mathrm{Brix}$, respectively. Total phenolic content (TPC) was assessed by a modified Folin-Ciocalteu colorimetric method and total antioxidant capacity (TAC) by the DPPH method reported by Brand-Williams et al. (1995) with modifications (Sanchez-Moreno et al. 1999). The data were expressed as milligrams of gallic acid equivalents (GAE/100 g fresh weight) and Trolox equivalent antioxidant capacity ( $\mu$ mol TE/100 g FW), respectively.

\subsection{Statistical analysis}

Statistical analysis was performed using the statistical software package Statgraphics18 (Manugistics, Inc., Rockville, MD, USA). The data were subjected to one way analyses of variance (ANOVA, F test), followed by a comparison of means according to the Duncan test. Treatments were declared different at $p=0.05$ level of significance. The analyses were performed in three replications and the obtained values were expressed as the means \pm standard error. 


\section{Results}

\subsection{Morphometric traits of plum fruits}

The present study revealed that fertilizer type and cultivar are important factors that significantly affect the morphometric traits of plum fruits, with the exception of the influence of cultivar on fruit width (Table 1). The largest fruits were recorded in biofertilizer treatment (weight - 37.96 g; length -47.99 $\mathrm{mm}$; width $37.28 \mathrm{~mm}$ ). With regard to the influence of cultivar, higher values for fruit weight $(37.14 \mathrm{~g})$ and length $(51.02 \mathrm{~mm})$ were observed in 'Stanley'.

Table 1

The influence of fertilizer type on fruit morphometric traits of plum cultivars

\begin{tabular}{clccc}
\hline Factor & & $\begin{array}{c}\text { Weight } \\
\text { (g) }\end{array}$ & $\begin{array}{c}\text { Length } \\
\mathbf{( m m})\end{array}$ & $\begin{array}{c}\text { Width } \\
\text { (mm) }\end{array}$ \\
\hline $\begin{array}{c}\text { Fertilizer } \\
\text { type } \\
\text { (A) }\end{array}$ & Chemical fertilizer & $37.96 \pm 0.87 \mathrm{a}$ & $47.99 \pm 2.10 \mathrm{a}$ & $37.28 \pm 0.28 \mathrm{a}$ \\
& Control & $35.66 \pm 1.56 \mathrm{ab}$ & $47.28 \pm 2.23 \mathrm{a}$ & $36.68 \pm 0.47 \mathrm{ab}$ \\
\hline $\begin{array}{l}\text { Cultivar } \\
\text { (B) }\end{array}$ & 'Čačanska Lepotica' & $32.43 \pm 1.38 \mathrm{~b}$ & $45.01 \pm 1.064 \mathrm{~b}$ & $35.70 \pm 0.37 \mathrm{~b}$ \\
\hline
\end{tabular}

\begin{tabular}{lccc}
\hline ANOVA & & $*$ & \\
\hline A & $*$ & $*$ & ns \\
B & $*$ & ns & ns
\end{tabular}

Data represent the means of three replicates \pm standard error. Values within each column followed by the same small letter are not significantly different at $p \leq 0.05$ by Duncan's test.

\subsection{Internal fruit quality}

The analysis of variance showed a significant effect of fertilizer type and cultivar on fruit internal quality with the exception of the influence of fertilizer type on the soluble solids content (Table 2). The highest fruit firmness (44.21 N) was recorded in biofertilizer treatment. With regard to the influence of cultivar on the internal quality traits of the fruit, a higher value of soluble solids content (19.98 ${ }^{\circ}$ Brix) was recorded in plum cv. 'Stanley', while fruit firmness was higher in 'Čačanska Lepotica' (46.98 N).

\section{Table 2}

The influence of fertilizer type on internal fruit quality traits of plum cultivars

\begin{tabular}{|c|c|c|c|}
\hline Factor & & $\begin{array}{c}\text { Soluble solids } \\
\text { ( }{ }^{\circ B r i x)}\end{array}$ & $\begin{array}{c}\text { Firmness } \\
\text { (N) }\end{array}$ \\
\hline & Biofertilizer & $17.90 \pm 1.16 \mathrm{a}$ & $44.21 \pm 3.59 \mathrm{a}$ \\
\hline \multirow[t]{2}{*}{ Fertilizer type (A) } & Chemical fertilizer & $17.74 \pm 1.19 \mathrm{a}$ & $37.52 \pm 4.61 \mathrm{ab}$ \\
\hline & Control & $17.23 \pm 1.17 \mathrm{a}$ & $35.12 \pm 4.06 \mathrm{~b}$ \\
\hline Cultivar & 'Čačanska Lepotica' & $15.26 \pm 0.09 \mathrm{~b}$ & $46.98 \pm 1.49 \mathrm{a}$ \\
\hline (B) & 'Stanley' & $19.98 \pm 0.58 \mathrm{a}$ & $30.92 \pm 2.54 \mathrm{~b}$ \\
\hline \multicolumn{4}{|l|}{ ANOVA } \\
\hline A & & ns & * \\
\hline B & & $*$ & * \\
\hline$A \times B$ & & ns & ns \\
\hline
\end{tabular}

Data represent the means of three replicates \pm standard error. Values within each column followed by the same small letter are not significantly different at $p \leq 0.05$ by Duncan's test 


\subsection{Total Phenolic Content (TPC) and Total Antioxidant Capacity (TAC)}

The results of our study related to the effects of fertilizer type on TPC and TAC in fruits of investigated plum cultivars are shown in Table 3. Fertilizer type showed a significant effect on TPC, as well as on TAC. Greater values of TPC and TAC were determined under biofertilizer treatment $(275.51 \mathrm{mg} / 100 \mathrm{~g} \mathrm{FW}$ and 3.10 Trolox, mmol/100 g FW, respectively). The other studied factor (cultivar) also showed a significant effect on TPC and TAC. The value of TPC $(273.35 \mathrm{mg} / 100 \mathrm{~g}$ FW) was higher in 'Stanley', while higher TAC (3.03 Trolox, mmol/100 g FW) was found in 'Čačanska Lepotica'.

Table 3

The influence of fertilizer type on TPC and TAC in fruits of plum cultivars

\begin{tabular}{|c|c|c|c|}
\hline Factor & & $\begin{array}{l}\text { Total phenolics } \\
\text { (mg/100 g FW) }\end{array}$ & $\begin{array}{l}\text { Total antioxidant capacity } \\
\text { (Trolox, mmol/100 g FW) }\end{array}$ \\
\hline \multirow{3}{*}{ Fertilizer type (A) } & Biofertilizer & $275.51 \pm 32.27 \mathrm{a}$ & $3.10 \pm 0.45 \mathrm{a}$ \\
\hline & Chemical fertilizer & $220.75 \pm 32.66 \mathrm{~b}$ & $2.60 \pm 0.35 \mathrm{~b}$ \\
\hline & Control & $134.81 \pm 21.34 \mathrm{c}$ & $1.44 \pm 0.13 \mathrm{c}$ \\
\hline Cultivar & 'Čačanska Lepotica' & $147.36 \pm 17.65 \mathrm{~b}$ & $3.03 \pm 0.35 \mathrm{a}$ \\
\hline (B) & 'Stanley' & $273.35 \pm 24.55 \mathrm{a}$ & $1.72 \pm 0.17 \mathrm{~b}$ \\
\hline
\end{tabular}

\section{ANOVA}

\section{A}

B

$\mathbf{A} \times \mathbf{B}$

$\begin{array}{ll}* & +2 \\ * & *\end{array}$

ns

ns

Data represent the means of three replicates \pm standard error. Values within each column followed by the same small letter are not significantly different at $p \leq 0.05$ by Duncan's test.

\section{Discussion}

\subsection{Morphometric traits of the fruit}

Fruit size has been discussed as one of the main components of yield. Due to their attractiveness, fruits of large size are preferred for the fresh market. Moreover, large sized fruits improve hand-harvest efficiency. The largest fruits recorded under biofertilizer treatment in both studied cultivars might be related to the stimulatory activity of microorganisms introduced into the soil by the biofertilizer used, thus resulting in increased nutrient ability and better solute uptake by the plants. Additionally, it may be due to the translocation of photosynthates to the fruit. In this regard, Kamatyanatti et al. (2019) reported that applications of Azotobacter and phosphate solubilizing bacteria in the rhizosphere of subtropical plum cultivar 'Kala Amritsari' enhanced the availability of $\mathrm{N}$ and $\mathrm{P}$ to the plant roots while also increasing their rate of translocation from roots to flowers by intensively developing an extensive extraradical mycelium which helps the plants exploit mineral nutrients and water from the soil. As determined in their study, the free living nitrogen fixer (Azotobacter) can affect plant growth not only by fixing nitrogen but also by altering microbial balance, solubilizing fixed soil phosphorus, suppressing pathogenic microorganisms and by producing metabolites that stimulate plant development. Singh et al. (2017) reported that the applications of Azotobacter may promote nitrogen fixation and biosynthesis of plant growth regulators (viz. IAA, GA3) and hence positively affect the growth of fruit trees. Some authors found that the positive impact of biofertilization can be further enhanced if these fertilizers are applied together with chemical fertilizers, FYM, green manures and/or vermicompost. In this regard, Thakur and Thakur (2014) recorded the highest plum yield in the combined application of biofertilizers, chemical fertilizers, FYM, vermicompost and green manures. Positive effects of the combined use of bio- and chemical fertilizers, and vermicompost on the growth of plum trees were also reported by Chauhan (2008). Von-Bennewitz and Hlusek (2006) also revealed positive effects of the combined application of chemical fertilizers (100\% NPK, 75\% NPK and 50\% NPK) and bio-fertilizers (Azotobacter, Azospirillum and vesicular arbuscular mycorrhiza) on the vegetative growth, productivity and quality traits of mango fruits.

\subsection{Fruit internal quality}

Bearing in mind that the tested cultivars are primarily intended for fresh consumption and the fact that soluble solids and fruit firmness are the two indicators of plum internal quality that most affect consumer acceptance (Paz et al. 2008), we thought that it was important to investigate the significance of the effect of fertilizer type on these parameters. Soluble solids content is an important factor which determines the eating quality of fruit. Vangdal et al. (2007) reported that plums with less than $12.5 \%$ of soluble solids were not acceptable for most consumers. On the other hand, fruit firmness is a good way to monitor fruit softening and to predict bruising damage during harvest and postharvest handling. Numerous authors recorded moderate to significant effects of orchard management practices on the soluble solids content 
and firmness of plum fruits. While studying the fruit quality parameters of several Japanese plum cultivars in organic and conventionally managed orchards, Daza et al. (2012) reported similar values of soluble solids concentration in both orchards. In their study, plum fruits under organic management showed equal or slightly greater firmness than under conventional treatment. Kamatyanatti et al. (2019) reported maximum firmness in treatment with biofertilizer along with $75 \%$ of $\mathrm{N}+12.5 \% \mathrm{~N}$ through vermicompost $+12.5 \% \mathrm{~N}$ through FYM in their study of the effect of integrated nutrient management on growth, flowering firmness and yield of subtropical plum cultivar 'Kala Amritsari'.

\subsection{Total Phenolic Content (TPC) and Total Antioxidant Capacity (TAC)}

Due to their health benefits, the demand for fruits with high levels of phytochemicals, in particular phenolic compounds, has received increasing attention from breeders, pharmaceutical companies and consumers. Plums contain a wide range of phenolics (Tomić et al. 2019; Sahamishirazi et al. 2017; Jaiswal et al. 2013; Miletić et al. 2012; Cevallos-Casals 2006; Kim et al. 2003; Stacewicz-Sapuntzakis 2001) which have been implicated in improving human health. The greatest benefit for human health is attributed to their antioxidant, anti-carcinogenic, antimutagenic, antimicrobial, anti-inflammatory and neuroprotective characteristics (Nile and Park 2014). However, the quantity and quality of bioactive compounds in fruits are strongly related to genotype (Tomić et al. 2019; Vizzotto et al. 2007; Scalzo et al. 2005), pre- and postharvest factors (Melgarejo et al. 2012; Díaz-Mula 2009) and also to the applied growing technologies (Peck et al. 2006; Veberic et al. 2005; Carbonaro et al. 2002). All these studies confirmed that fruits produced without the use of synthetic products (fertilizers and plant protection products) have a higher amount of micronutrients and health-related secondary metabolites, such as phenolic compounds. When studying the effect of organic and conventional management on the bio-functional quality of thirteen plum cultivars (Prunus salicina Lindl.), Cuevas et al. (2015) recorded 5-10\% higher TPC and TAC of plum fruits under organic production management. In their study, an increased synthesis of phenolic compounds might be attributed to the production without pesticides and chemical fertilizers. The increase of the TPC and TAC of plum fruits could be explained by similar reasons. Our study revealed that 'Stanley' was the richest in TPC, whereas higher TAC was found in 'Čačanska Lepotica'. The pronounced influence ofgenotype was confirmed by Tomić et al. (2019) in their study on the phytochemical assessment of 18 plum cultivars, with 'Stanley' showing the highest content of total phenols, thus being categorized into a group of cultivars with a high content of total phenols.

\section{Conclusion}

The results presented in this study reveal that fertilizer type is an important factor that significantly affects plum production. Applications of biofertilizers containing beneficial microorganisms (Azotobacter chroococcum, Bacillus megatherium and Bacillus subtilis) in plum growing technology had a positive effect on fruit morphometric traits, soluble solids content and firmness, as well as on TPC and TAC in both studied cultivars. Since this technique has been shown to be sustainable, it can be recommended for use in commercial plum production. However, further field trials should be conducted to establish a proper rate and frequency of applications in order to obtain the most beneficial influence on yield and fruit quality.

\section{Acknowledgement}

This work was supported by the Ministry of Education, Science and Technological Development of the Republic of Serbia, Contracts No. 451-03-68/2020$14 / 200215$ and 451-03-68/2020-14/200088. We hereby express our sincere gratitude for the support. We also wish to thank our language editor Mira Lazović.

\section{References}

Bockman, O.C., Kaarstad, O., Lie, O.H., Richards, I. (1990). Agriculture and fertilizers. Agr Group, Norsk Hydro a.s., Oslo.

Brand-Williams, W., Cuvelier, M.E., Berset, C. (1995). Use of a free radical method to evaluate antioxidant activity. Brazilian Journal of Food Technology, 28, 25-30.

Carbonaro, M., Mattera, M., Nicoli, S., Bergamo, P., Cappelloni, M. (2002). Modulation of antioxidant compounds in organic vs conventional fruit (peach, Prunus persica L., and pear, Pyrus communis L.). Journal of Agricultural and Food Chemistry, 50, 19, 5458-5462.

Cevallos-Casals, B.A., Byrne, D., Okie, W.R., Cisneros-Zevallos, L. (2006). Selecting new peach and plum genotypes rich in phenolic compounds and enhanced functional properties. Food Chemistry, 96, 273-280.

Chauhan, A. (2008). Studies on integrated nutrient management in plum cv. Santa Rosa. Ph.D. Thesis. Dr Y. S. Parmar University of Horticulture and Forestry, Nauni, Solan, H.P. (India).

Cuevas, F.J., Pradas, I., Ruiz-Moreno, M.J., Arroyo, T.F., PerezRomero, L.F., Montenegro, J.C., José Moreno-Rojas, M. (2015). Effect of Organic and Conventional Management on Bio-Functional Quality of Thirteen Plum Cultivars (Prunus salicina Lindl.). PLoS ONE, 10, 8: e0136596.

Daza, A., Camacho, M., Galindo, I., Arroyo, F.T., Casanova, L., Santamaría, C. (2012). Comparative fruit quality parameters of several Japanese plum varieties in two newly established orchards, organic and conventionally managed. International Journal of Food Science \& Technology, 47, 2, 341-349.

Díaz-Mula, H., Zapata, P., Guillén, F., Martínez-Romero, D., Castillo, S., Serrano, M., Valero, D. (2009. Changes in hydrophilic and lipophilic antioxidant activity and related bioactive compounds during postharvest storage of yellow and purple plum cultivars. Postharvest Biology and Technology, 51, 3, 354-363.

Jaiswal, R., Karaköse, H., Rühmann, S., Goldner, K. Neumüller,M., Treutter, D., Kuhnert, N. (2013). Identification of phenolic compounds in plum fruits (Prunus salicina L. and Prunus domestica L.) by highperformance liquid chromatography/ tandem mass spectrometry and characterization of varieties by quantitative phenolic fingerprints. Journal of Agricultural and Food Chemistry, 61, 49, 12020-12031.

Kamatyanatti M., Kumar A., Dalal R.P.S. (2019): Effect of integrated nutrient management on growth, flowering and yield of subtropical plum cv. Kala Amritsari. Journal of Pharmacognosy and Phytochemistry, 8, 1: 1904-1908.

Kim, D., Jeong, S.W., Lee, C.Y. (2003). Antioxidant capacity of phenolic phytochemicals from various cultivars of plums. Food Chemistry, 81, 3, 321-326. 
Lévai, L., Veres, S., Bákonyi, N., Gajdos, É. (2008). Can wood ash and biofertilizer play a role in organic agriculture? Agronomski Glasnik, 3, 263-271.

Melgarejo, P., Calín-Sánchez, Á., Hernández, F., Szumny, A., Martínez, J., Legua, P. (2012). Chemical, functional and quality properties of Japanese plum (Prunus salicina Lindl.) as affected by mulching. Scientia Horticulturae, 134, 114-120.

Mansour, A.E.M., Ahmed, F.F, Abdelaal, A.M.K, Eissa, R.A.R., Amira A.F. (2011). Selecting the best method and dose of yeast for Kelsey plum trees. Journal of Applied Sciences Research, 7, 1218-1221.

Miletić, N., Popović, B., Mitrovi,ć O., Kandić, M. (2012): Phenolic content and antioxidant capacity of fruits of plum cv. 'Stanley' (Prunus domestica L.) as influenced by maturity stage and on-tree ripening. Australian Journal of Crop Science, 6, 4, 681-687.

Milošević, T., Milošević, N., Mratinić, E. (2010): Morphogenic variability of some autochthonous plum cultivars in Western Serbia. Brazilian Archives of Biology and Technology, 6, 1293-1297.

Mosa, A.E.W.F., Sas, Paszt L., Abv El-Megeed, N.A. (2014). The role of biofertilization in improving apple productivity. Advances in Microbiology, 4, 1057-1064.

Mosa, A. E. W. F., Sas Paszt, L., Frac, M., Trzcinski, P. (2015). The role of bio-fertilization in improving fruits productivity. Advances in Microbiology, 5, 21-27.

Nile, S.H., Park, S.W. (2014). Edible berries: Bioactive components and their effect on human health. Nutrition, 30, 134-144.

Paz, P., Sánchez, M.T., Pérez-Marín, D, Guerrero, J.E., GarridoVaro, A. (2008). Nondestructive determination of total soluble solid content and firmness in plums using nearinfrared reflectance spectroscopy. Journal of Agricultural and Food Chemistry, 56, 8, 2565-2570.

Peck, G.M., Andrews, P.K., Reganold, J.P., Fellman, J.K. (2006) Apple orchard productivity and fruit quality under organic, conventional, and integrated management. Hortscience, 41, 1, 9-107.

Pešaković, M. (2007). Microbial activity and productivity of alluvium under plum trees. Doctoral Thesis. University of Kragujevac, Faculty of Agronomy Čačak (Serbia): 1-151.

Pesakovic, M., Djukic, D., Mandic, L., Miletic, R. (2012). Microbiological activity and productivity of soil in plum orchard. Journal of Environmental Protection and Ecology, 13, 951-959.

Pešaković, M., Glišić, I., Tomić, J., Lukić, M., Karaklajić-Stajić, Ž. (2016). Environmental safety and innovative plum growing technology. International conference 'Bonding tradition with innovation successful strategies in food chain value', Olsztyn (Poland), 36.

Pešaković, M., Tomić, J., Lukić, M. (2017). Advances in Fruit Growing Technology. In: Gorawala P., Mandhatri S. (eds),
Agricultural Research Updates, Nova Science Publishers, Inc, New York, 141-187.

Sahamishirazi, S., Moehring, J., Claupein, W., GraeffHoenninger, S. (2017). Quality assessment of 178 cultivars of plum regarding phenolic, anthocyanin and sugar content. Food Chemistry, 214, 694-701.

Sánchez-Moreno, C., Larrauri, J.A., Saura-Calixto, F.A. (1999). A procedure to measure the antiradical efficiency of polyphenols. Journal of Agricultural and Food Chemistry, 76, 270-276.

Scalzo, J., Politi, A., Pellegrini, N., Mezzetti, B., Battino, M. (2005). Plant genotype affects total antioxidant capacity and phenolic contents in fruit. Nutrition, 21, 2, 207-213.

Singh, S.K., Thakur, N., Sharma, Y. (2012). Effective nutrient management in fruit crops. Asian Journal of Horticulture, 7, 2, 606-609.

Singh, Y., Satya, P., Om, P., Dharmendra, K. (2017). Effect of integrated nutrient management on fruit yield and quality of Amrapali mango (Mangifera indica L.) under high density planting. International Journal of Pure \& Applied Bioscience, 5, 3, 67-73.

Stacewicz-Sapuntzakis, M., Bowen, P.E., Hussain, E.A. Damayanti-Wood, B.I., Farnsworth, N.R. (2001): Chemical composition and potential health effects of prunes: a functional food? Food Sciences and Nutrition, 41, 4, 251286.

Thakur, N., Thakur, B.S. (2014). Studies on the effect of integrated nutrient management on growth and yield of plum cv. Santa Rosa. Asian Journal of Horticulture, 9, 112115.

Tomić, J., Štampar, F., Glišić, I., Jakopič J. (2019): Phytochemical assessment of plum (Prunus domestica L.) cultivars selected in Serbia. Food Chemistry, 299, 125113

Vangdal, E., Flatland, S., Nordbø, R. (2007). Fruit quality changes during marketing of new plum cultivars (Prunus domestica L.). Horticultural Science, 34, 3, 91-95.

Veberic, R., Trobec, M., Herbinger, K., Hofer, M., Grill, D., Stampar, F. (2005). Phenolic compounds in some apple (Malus domestica Borkh) cultivars of organic and integrated production. Journal of the Science of Food and Agriculture, 85, 10, 1687-1694.

Vizzotto, M., Cisneros-Zevallos, L., Byrne, D.H., Ramming, D.W., Okie, W. (2007). Large variation found in the phytochemical and antioxidant activity of peach and plum germplasm. Journal of the American Society for Horticultural Science, 132, 3, 334-340.

Vlahović, B., Zdravković, Z. (2016). State and trends of plum exports from the Republic of Serbia. Agrieconomica, 72, 21-28.

Von-Bennewitz, E., Hlusek, J. (2006). Effect of the application of two bio-preparations on the nutritional status, vegetative and generative behaviour of Jonagold apple trees. Acta Horticulturae, 721, 129-136. 